Çukurova Üniversitesi Mühendislik Mimarlık Fakültesi Dergisi, 34(2), ss. 57-72, Haziran 2019

Çukurova University Journal of the Faculty of Engineering and Architecture, 34(2), pp. 57-72, June 2019

\title{
Atık Isı Geri Kazanım Sistemlerine Yönelik Literatür Araştırması ve Sanayiden Örnek Vaka İncelemesi
}

\author{
Nehir TOKGÖZ*1, Ömer ÖZGÜN \\ ${ }^{1}$ Osmaniye Korkut Ata Üniversitesi, Mühendislik Fakültesi, Enerji Sistemleri Mühendisliği \\ Bölümü, Osmaniye
}

Geliş tarihi: 16.01.2019Ｋabul tarihi: 28.06.2019

\section{Özet}

Yaşanan hızlı nüfus artışı, sanayileşme oranının yükselmesi ve teknolojideki gelişmeler enerjiye duyulan ihtiyacı günden güne arttırmaktadır. Dünya genelinde birçok endüstriyel tesise ait enerji tüketiminin yaklaşık olarak dörtte birinin atmosfere atılan atık gazlar ile kaybolduğu varsayılmaktadır. Çok büyük miktarda olan bu kaybın tekrar kazanılması geri kazanım sistemleri ile mümkün hale gelmektedir. Bu çalışmada atık ısı geri kazanım sistemleri üzerine yapılmış olan daha önceki çalışmalar sınıflandırılarak incelenmiştir. Ayrıca örnek bir vaka çalışması yapılarak doğalgaz yakıtlı bir kazan için baca gazı ısı geri kazanım potansiyeli araştırılmış, atık baca gazındaki ısıdan yararlanmak amacıyla 1sı geri kazanım sistemi (reküperatör) tasarlanmıştır. Tasarlanan sistem için; enerji analizleri, 1sı transfer analizleri ve ekonomik analizler yapılmış, sistemin 15 yıllık ekonomik ömrü boyunca sağlayacağı yakıt tasarrufu, Net Bugünkü Değer Metodu ile 1.121.410,23 TL olarak hesaplanmıştır.

Anahtar Kelimeler: Atık 1sı, Atık 1sı geri kazanım sistemleri, Reküperatör, Isı transferi

\section{A Review on Waste Heat Recovery Systems and a Case Study from Industry}

\begin{abstract}
Rapid population growth, increase in the industrialization rate and technological developments increase the need for energy day by day. It is assumed that about one-fourth of the energy consumption of many industrial plants throughout the world is lost waste gases discharged into the atmosphere. Recovering this huge waste heat is possible with heat recovery systems. In this study, literature review and classifications on waste heat recovery systems have been investigated. In addition, a case study was conducted to investigate the potential of exhaust gas heat recovery for a natural gas-fired boiler. Results led us design a heat recovery system to utilize the waste heat from the exhaust gas. For this design; energy, heat transfer and economic analysis have been made and the fuel savings of the system was calculated 1.121.410, 23 TL for 15 years economic life with present value method.
\end{abstract}

Keywords: Waste heat, Waste heat recovery systems, Recuperator, Heat transfer

*Sorumlu (Başlıca) yazar (Corresponding author): Nehir TOKGOZ, nehirtokgoz@osmaniye.edu.tr 


\section{GíRiş}

Dünyada ve ülkemizde hılı nüfus artışı ve sanayideki gelişmeler ile doğru orantılı olarak enerji ihtiyacı her geçen gün artmaktadır. Mevcut enerji kaynakları artan enerji ihtiyaçlarını karşılayamaz duruma gelmiştir. Bunun sonucunda enerji verimliliği kavramı ortaya çıkmıştır. Harcanan enerji miktarının, üretimden elde edilen ürün miktarını ve kalite oranını düşürmeden, ekonomik gelişmeleri ve sosyal refahı olumsuz etkilemeyecek şekilde en aza indirilmesi enerji verimliliği olarak adlandırılmaktadır.

Başka bir deyişle enerji verimliliği; sistemdeki gaz, buhar, 1s1, hava ve elektriksel enerji kayıplarını engellemek, sistemden atık olarak uzaklaştırılan oluşumların geri kazanımı ve tekrar değerlendirilmesi veya üretim miktarını düşürmeden ihtiyaç duyulan enerji ihtiyacının azaltılması, verimi daha yüksek enerji kaynakları, daha gelişmiş endüstriyel süreçler, enerji geri kazanımı gibi verimlilik arttırıcı önlemlerin tamamıdır. Enerji verimliliğinde esas olan herhangi bir tasarrufa veya kısitlamaya gidilmeden enerjinin etkin bir şekilde kullanılarak tüketimin azaltılmasıdır. Üretim kapasitesi yüksek ve enerji tüketimi fazla olan sanayi tesislerinde enerjinin verimli bir şekilde kullanılması maliyetleri düşürdüğü gibi enerji eldesi için gerekli olan kaynak tüketimini de ciddi derecede azaltmaktadır [1].

Dünya genelinde birçok endüstriyel tesise ait enerji tüketiminin yaklaşık olarak dörtte birinin atmosfere atılan 1sı ve gaz ile kaybolduğu varsayılmaktadır [2].

Çok büyük miktarda olan bu kaybın tekrar kazanılması geri kazanım sistemleri ile mümkün hale gelmektedir. İlk yatırım maliyetleri yüksek olduğu halde uzun vadede sağladığı faydalardan dolayı endüstriyel tesislerde geri kazanım sistemleri kurulmaya başlanmıştır. Geri kazanım sistemleri hem endüstriyel tesislerin enerji ihtiyaçları için ayırdıkları payı azaltmakta hem çevreye verdiği zararı düşürmekte hem de enerjinin en verimli şekilde kullanılmasını sağlamaktadır [2]. Örneğin; endüstriyel bir kazanda verim yaklaşık \%75 civarında, enerji kayıpları (boru kayıpları, radyasyon ve konveksiyon kayıpları, sicak baca gaz kayıpları) yaklaşık \%25 civarındadır. Geleneksel bir buhar kazanında üretilen enerjinin takribi \%16-20 kadarı atık 1s1 olarak baca gazları ile beraber sistemden ayrılmaktadır. Oranın yüksek olması, geri kazanım sistemlerinin baca gazları için önemini açıkça göstermektedir [3].

\section{2. ÖNCEKİ ÇALIŞMALAR}

Endüstriyel tesislerde maliyeti oluşturan en büyük ana girdilerden biri enerji olduğu için, işletmelerinin her bölümünde enerji verimliliği ile ilgili çalışmalar yapılmaktadır. Tesislerin en büyük enerji kayıplarından birini ise atık ısılar oluşturmaktadır. Bu kaybı azaltabilmek için 1s1 enerjisinin kullanıldığı hemen hemen her sektörde atık ısı geri kazanım sistemleri kullanılmaktadır. Herhangi bir üretim işlemi sonrası açığa çıkan ve atmosfer sıcaklığının üzerinde bir sicaklıkta bulunan 1sıya atık 1sı, bunları geri kazanmak için tasarlanan sistemlere de atı 1 s1 geri kazanım sistemleri denilmektedir. Atık 1s1 sicaklık değerlerine göre $650{ }^{\circ} \mathrm{C}$ üzerindeki yüksek sıcakta 1s1, $120{ }^{\circ} \mathrm{C}-650{ }^{\circ} \mathrm{C}$ arasi orta sicaklikta 1s1 ve $120{ }^{\circ} \mathrm{C}$ altındaki düşük sıcaklıkta 1 sı olmak üzere sinıflandırılabilir. Atık 1s1 ve geri kazanılmasıyla ilgili bilim adamları tarafından yapılan birçok çalışma mevcuttur. Yapılan çalışmalardan bir kısmı sınıflandırılarak özetlenmeye çalışılmıştır.

\subsection{Isı Borusu ile Atık Isı Geri Kazanımının Incelendiği Çalışmalar}

Güngör, son yıllarda değişik, verimli ve çok üstün uygulamaları ile yaygın bir kullanım alanı bulan 1sı borularının; temel prensipleri, kullanılan malzemeler, çalışma akışkanları üzerine inceleme yapmış, 1s1 borulu 1sı değiştiricilerin enerji geri kazanım ve özellikle iklimlendirmedeki uygulamalarını incelemiştir [4]. Ersöz, 1Sı borusu vasıtasıyla atık ısıların geri kazanımı için baca gazlarından yararlanma yolu deneysel olarak incelenmiştir. Elde edilen sonuçlar yorumlanarak ne kadarlık bir 1sı kazancı olduğu incelemiştir [5]. Ersöz yaptığı bir diğer çalışmasında [6] 1sı borusu 
yardımıyla baca gazları ile atılan ısının geri kazanılmasını deneysel olarak incelemiştir, inceleme sonuçlarında ise baca gazı sıcaklığının derecesine bağlı olarak ısıtılmak istenilen akışkanda elde edilen sıcaklık değerlerini yorumlamıştır.

Ürün, [7] 1sı borulu atık baca gazlarından geri kazanılabilecek 1sı için kurulu bir sistemin 1sıl performansını deneysel olarak incelemiştir. Sistem için, R-134a soğutucu akışkanın, R-410a soğutucu akışkanına göre daha etkili olduğunu ortaya koymuştur.

Remeli, [8] bir 1sı borusu termoelektrik jeneratörü kullanarak, 1sı geri kazanım ve güç üretimi için pasif bir 1sı transferi sistemi geliştirmiştir. Sistemin, aynı anda atık 1sıyı geri kazanma ve herhangi bir yardımcı güç olmaksızın tamamen pasif bir sistemden elektrik enerjisi üretme potansiyeline sahip olduğunu ortaya koymuştur.

Jouhara, [9] çelik endüstrisinde kullanılmak üzere düz 1sı borusu 1sı değiştiricisi ile ısı geri kazanım sisteminin tasarımı ve üretimini incelemiştir. Çalışmasının sonucunda düz 1S1 borusu 1S1 değiştiricisinin endüstriyel uygulamalarda atık 1sı geri kazanımı için yenilikçi yüksek verimli bir teknoloji olduğunu belirtmiştir.

\subsection{Eşanjör Uygulamaları ile Atık Isı Geri Kazanımının İncelendiği Çalışmalar}

Oğulata ve Doba, [10] yaptıkları çalışmalarında, atık 1sı geri kazanım sistemlerindeki yüksek verimlerinden dolayı çapraz akışlı levhalı tip 1S değiştiricisini incelemişlerdir. Sıcaklık, hava hızı ve sistemdeki basınç kayıplarını ölçmüş ve sistemin etkinliğini belirlemişlerdir.

Şahan, [11] çalışmasında HVAC sistemlerinde, plakalı 1sı değiştiricisi ile yapılabilecek geri kazanım uygulamalarını incelemiş, havadan havaya plakalı eşanjörler kullanıldığında, projede meydana gelen değişiklikleri ve elde ettiği bulguları örnekler üzerinde değerlendirmiştir.

Atalay, [12] atık 1sı geri kazanımı sağlamak için kullanılan döner tip 1sı değiştiricisini incelemiştir.
Eşanjörün etkinliği için dönme hızı ve hava debisine bağlı olarak deneysel, analitik ve sayısal hesaplamalar yapmıştır. Belirli bir değere kadar dönme hızının artmasıyla, 1S1 değiştiricisi tarafından taşınan sıvının arttığını ve akış hızının azalmasıyla, etkililiğin arttığını belirtmiştir. Goel, [13] çalışmasında baca gazı atık 1sısı ve atık su geri dönüşümü için yoğuşmalı 1sı değiştiricisi tasarlamış ve performans analizlerini yapmıştır.

\subsection{Isı Pompası ile Atık Isı Geri Kazanımının İncelendiği Çalışmalar}

Yamankaradeniz, [14] bir tekstil fabrikasından elde ettiği verileri kullanarak atık 1sıdan enerji geri kazanımından kullanılan klasik sistemlerle 1s1 pompası sistemlerinin karşılaştırılmasını yapmıştır. Boyahaneden $65^{\circ} \mathrm{C}$ 'de çıkan atık suyun enerjisinden yararlanmak için kullanılan plakalı 1sı eşanjörü yerine 1sı pompası kullanılması halinde, yeni sisteme ait ekonomik analizleri yapmış, yıllık enerji tasarruf miktarları ve geri ödeme süreleri hesaplanmıştır.

Yamankaradeniz yapmış olduğu bir diğer çalışmada, [15] enerji geri kazanımı sağlamak için iki farklı prototip 1S1 pompası deney tesisatı tasarlamıştır. İlk çalışmada, endüstride kullanılan kurutma proseslerinde, kurutma odasından çıkan nemli ve sicak havanın 1sısını geri kazanmak amacıyla, ikinci çalışmada ise endüstride birçok proses sonucu açığa çıkan ve drenaja atılan düşük sicaklıktaki atık sıvılardan faydalanmak amacı ile prototip 1S1 pompası tesisatı kurmuştur. Her iki çalışmasının sonucunda ısı pompası kullanımının oldukça verimli olduğu ortaya koymuştur.

Muslu, [16] 1sı pompası destekli 1sı geri kazanım cihazının farklı sicaklıklardaki performans analizlerini yapmış, ülkemizde üretilen bir 1s1 pompası destekli 1s1 geri kazanım cihazını kullanmış ve farklı sıcaklıklarda performans ölçümlerini yapmıştır.

Farshi, [17] kademeli sıkıştırma-emme 1sı pompası adı verilen yeni bir 1sı pompası tasarlayarak diğer 1S1 pompaları (sıkıştırma, soğurma ve hibrid sıkıştırma-emme) ile karşılaştırılmıştır. Dört farklı 1S1 pompasının özelliklerini belirlemek için enerji ve ekserji analizlerini yaparak karşılaştırılmıştır. 


\subsection{Ekonomizer ile Atık Isı Geri Kazanımının İncelendiği Çalıșmalar}

Gibbs, [18] bir kazana ekonomizer takılması ile elde edilecek yakıt tasarrufunu incelemiştir. Yapılan çalışmalar sonrasında yakıt tasarrufunun \%6-16 arasında olduğunu ortaya koymuştur.

Butcher ve Litzke, [19] çalışmalarında, yakıt olarak kömür kullanılan kazanlarda kullanılan yoğuşmalı ekonomizerlerin verimliliğini ve baca gazına ait çıktıların emisyon kontrolleri açısından olası kullanımlarını hesaplamışlardır. Çalışmalarında, 1sı transfer hesaplamaları yaparak bu tür kazanlara entegre edilen hava ve su soğutmalı ekonomizerlerle ile ilgili deneysel incelemeler yapmışlardır.

Çıtır, [20] ray ve profil haddehanesinde bulunan tav firınında ekonomizer kullanılması durumunda atık 1sı geri kazanım çalışması yapmıştır. Çalışmasında baca gazı ölçümleri sonuçları alıp, kütle ve enerji denkliklerini elde ederek ekonomizerden enerji kullanım imkanları, tasarım kriterleri ve amortisman süreleri hesaplanmıştır. Ekonomizerin \%84 verimle çalıştığı tespit etmiş ve ekonomizer kullanımı sonucu y1llık kazancın toplamda 513,916 €, sistemin amortisman süresinin ise 3,6 yıl olacağını hesaplamıştır.

He, [21] kömürle çalışan elektrik santrali için düşük basınçlı ekonomizeri atık 1sı geri kazanım sistemi olarak tasarlamış ve termodinamik analizlerini yapmıştır. Düşük basınçlı ekonomizerin kullanılmasıyla, egzoz baca gazı içerisindeki ısının etkin bir şekilde geri kazanılabileceğini ve aynı zamanda su tüketiminin de azaltılabileceğinden bahsetmiştir.

Kılınç, [22] demir çelik sektöründeki endüstriyel bir tesise ait tav firını bacasından atılan atık gazın ekonomizer vasıtasıyla geri kazanılması sonucu elde edilen 1s1 enerjisinin merkezi 1sitma-soğutma sistemlerinde ve sicak su kullanım yerlerinde kullanılabilirliği incelenmiştir. Fırın bacasından atılan gazın sıcaklığına bağlı olarak isıl kapasite hesaplamaları ve optimum değerler tespit edilmiştir. Yapılan hesaplamalar neticesinde tesisin ihtiyacı olan sicak suyun, ekonomizer vasitasiyla geri kazanılan atık ısı enerjisi ile elde edilmesi sonucu yıllık yaklaşık olarak 6.300.000 TL'lik tasarruf sağlandığı hesaplanmıştır.

\subsection{Reküperatör ile Atık Isı Geri Kazanımının İncelendiği Çalışmalar}

Aras, [23] baca gazlarını kullanarak kazan ön yakma havasının 1sitılması ve sıcak su temini için bir reküperatör tasarımı yapmıştır. Çalışma sonucunda, kazan veriminin \%92'den \%99'a yükseleceğini, reküperatör kullanımı sonucu $5 \mathrm{Nm}^{3} / \mathrm{h}$ yakıt tasarrufu sağlanabileceğini göstermiştir.

Selimli, [24] bir tesisin tav firınında, yakıt optimizasyonu sağlamak ve yüksek enerjili firın egzoz gazından $\left(700{ }^{\circ} \mathrm{C}-850{ }^{\circ} \mathrm{C}\right)$ firın yakma havasına 1sı transfer sağlamak amacıyla reküperatör tasarlamıştır. Tasarlanan reküperatör vasıtası ile $820^{\circ} \mathrm{C}$ baca gazı sıcaklığı ile $575^{\circ} \mathrm{C}$ yakma havası elde edilmiştir. Bu sayede enerji geri kazanımı ve emisyon azalımı sağlanırken, ayrıca yüksek kaliteli ürün ve düşük maliyetli üretim elde edilmiştir.

\subsection{Kazan Uygulamalarında Atık Isı Geri Kazanımının İncelendiği Çalışmalar}

Willems, [25] endüstriyel kazanlar için gelişmiş sistem kontrolleri ve enerji tasarrufu yöntemlerini incelemiş, kazanlarda enerji tasarrufu için uygulanabilecek yöntemleri anlatmıştır.

Cortina, [26] çalışmasında biyo-yakıtlı kazanlar için kondenserlerin önemini vurgulamış, kondenser kullanılarak geri kazanılabilecek ısıdan bahsetmiştir.

Ünlü, [27] buhar kazanının verimini yükseltmek için, kazan yüzey blöfünün yapılması ve blöften enerji kazanımı, kondensin geri döndürülmesi, buhar kapanlarındaki buhar kaçaklarının önlenmesi, atık ısıdan ve flaş buhardan 1sı geri kazanımı üzerine çalışmalar yapmıştır.

Terhan, [28] Atatürk Üniversitesi’nde kurulu bulunan 1sitma merkezindeki kazanlardan egzoz gazı olarak dışarıya atılan atık enerjinin geri kazanımı ve atılan enerjinin tesislerde kullanım potansiyelini araştırmıştır. Neticede, egzoz edilen 
baca gazı enerjisinin sistemde yeniden kullanımı ile kazan veriminin artacağı, yakıt tasarrufu sağlanacağı ve mahal ile sicak su isitılmasinda kullanılabileceğini tespit etmiştir. Yapılan hesaplamalar sonucunda yillık 413.673,07 $\mathrm{m}^{3}$ yakıt tasarrufu sağlanabileceği görülmüştür.

Wang, [29] endüstriyel buhar kazanı atık 1sısı ve su geri kazanımı için geliştirilen membran bazlı yoğuşturucu teknolojisi incelenmiştir. Egzoz su buharının \%40 oranında azaltıldığı ve toplam verimliliğin \%5’ten fazla bir artış gösterildiği görülmüştür.

Görgülü, [30] bir tesiste baca gazından çıkan atık 1S1 enerjisini geri kazanarak çift etkili absorbsiyonlu soğutma sistemi tasarlamıştır.

\subsection{Atık Isı Geri Kazanımında ORÇ Uygulamalarının İncelendiği Çalışmalar}

Yağl1, [31] bir tav firınının bacasından atmosfere atılan egzoz gazı atık 1sısını kullanması için organik Rankine çevrimi tasarlamıştır. ORÇ tasarımı toluen akışkanı kullanılarak yapılmış ve ardından çevrimin iyileştirilmesi için farklı akışkanlar incelenmiştir. Her bir akışkan için enerji ve ekserji analizleri yapılmıştır.

Peris, [32] seramik endüstrisinde düşük dereceli atık 1S1 geri kazanımında organik Rankine çevriminin deneysel olarak uygulanmasını yapmıştır. Çalışmasında, organik Rankine çevriminin gerçek endüstriyel koşullarda performansını doğrulamak ve uygulamanın kârlılığını değerlendirmeyi amaçlayan araştırmacı, laboratuvar ve endüstriyel uygulama testlerinin ORÇ performans verilerinden, 1s1 geri kazanım sistemi modeli geliştirilmiştir. Modelin kullanılması ile beraber, çalışma yılı boyunca sistemin elektrik üretimi simüle edilerek 115 MWh üzerinde enerji üretimi elde edilmiştir. Seyedkavoosi, [33] içten yanmalı bir motordan atık ısı geri kazanımı için iki kademeli organik Rankine çevriminin ekserji analizini yapmıştır. Is1 geri kazanım sistemi için çalışma sıvıları R-123, R-134a ve su seçilmiştir. Sonuçlar, dikkate alınan koşullar altında R-123’ün, \%21'lik bir ekserji verimi ve 468 kW'lık net güç üretmesi sebebi ile sistem için en iyi çalışan akışkan olduğunu ortaya koymuştur.
Ramirez, [34] bir çelik fabrikasında atık 1Sı geri kazanım ünitesi ile birlikte büyük ölçekli bir organik Rankine çevrimi pilot tesisi tasarlanmıştır. Atık 1sı, doymuş buhar üretmek için elektrikli ark ocağının dumanlarından geri kazanılmış ve daha sonra isıtma mevsiminde bir bölgesel 1sıtma tesisatına ve y1lın geri kalanında da elektrik üretimi için organik Rankine çevrimine gönderilmiştir. Organik Rankine çevriminin nominal güç çıkışı 1,8MW ve net verimlilik \%21,7 olarak hesaplanmıştır.

\subsection{Gaz Türbinlerinde Atık Isı Geri Kazanımının İncelendiği Çalışmalar}

Srikanth, [35] dizel yakıtı kullanan gaz türbininin egzoz gazını kullanarak atık 1s1 geri kazanım kazanlarında, kazan borularının korozyondan kaynaklanan arızalarını analiz etmiştir. Kazanın düşük sıcaklıktaki bölgelerinde yüksek korozyon eğilimi ve buna bağlı arızaların, bu bölgelerdeki hidratlı ferrik sülfat oluşumu ile doğrudan ilişkili olduğu bulunmuştur.

Yaylac1, [36] enerji sektörünün en önemli donanımlarından biri olan gaz türbini, atık 1S1 kazan1, konvansiyonel kazan ve buhar türbinlerinden oluşan TÜPRAŞ İzmit Rafinerisi kuvvet santrali ünitesinin simülasyon modelini hazırlanmıştır. Kullanmış olduğu program vasıtası ile sisteme ait termodinamik hesaplamalar yapmıştır. Sistemin ekserji analizini yaparak ekserji veriminin optimizasyonunu yapmıştır.

Sharma, [37] gemi gaz türbininde kritik üstü ve transkritik karbondioksitin kullanılması sonucu elde edilecek gücün termodinamik analizlerini yapmıştır. Belirtilen çalışma koşulları altında önerilen sistemin, sağlayacağı güç çıktısını yaklaşık \%18 arttırma potansiyeline sahip olduğunu bulmuştur. Ayrica, kullanılan sistem ile beraber genel verimin \%11'den fazla arttığını tespit etmiştir.

\subsection{Sektörel Bazlı Yapılan Çalışmalar}

\subsubsection{Tekstil Sektöründe Atık Isı Geri Kazanımının İncelendiği Çalışmalar}

Can, [38] boyama işleminden elde edilen atık ısının geri kazanım potansiyelini değerlendirmiştir. Sudan suya gövde ve boru 1sı eşanjörü ile atık 1s1 
geri kazanım sisteminin etkin çalıșma koşullarını optimize etmek için ekserji temelli bir yaklaşım uygulanmıştır. Atık su giriş sıcaklığı, kütle akış hızı, soğutma suyu giriş basıncı ve referans durum koşulları gibi sistem performansını etkileyen parametreler incelenmiştir. Koçlu, [39] boyama işlemi sonrası atılan yüksek yoğunluktaki ve yüksek sıcaklıktaki akışkanların plakalı 1sı değiştirici yardımıyla geri kazanımını ve sistemin performans analizlerini incelemiştir. Sistemin kurulması ile birlikte $1 \mathrm{~kg}$ pamuk boyama için harcanan doğalgaz miktarında aylık ortalama \%28,36 oranında bir azalma kaydedilmiştir.

\subsubsection{Demir-Çelik Sektöründe Atık Isı Geri Kazanımının İncelendiği Çalışmalar}

Kaşka, [40] çelik endüstrisinde kullanılan tav fırınların atılan ısının geri kazanımı için kullanılan organik Rankine çevriminin performansını incelemiştir. Evaporatör ve yoğuşturucu basınçları, buharlaştırıcı çıkışındaki aşırı 1sınma, yoğunlaştırıcıdaki aşırı soğutma ve buharlaştırıcıdaki 1sı değişiminin sıkışma noktası sıcaklık farkı gibi bazı çalışma parametrelerinin incelenmesi, tesisin çalışması ve 1 sı çevrimi prosesine dair önemli bilgiler vermiştir. Eyidoğan, [41] endüstriyel bir tesise ait sıvılaştırılmış doğalgaz (LNG) yakıtlı haddehane tav firınında enerji verimliliği çalışmaları yapmıştır. Fırın verimliliği ve tasarruf potansiyellerini hesaplayabilmek için çeşitli ölçümler yapmıştır. Ölçüm sonuçlarından elde edilen verileri kullanarak enerji-kütle denklikleri kurmuştur. Hesaplamalar sonucunda firın genel verimi \%52,76 olarak hesap etmiştir. Tav fırınında yapilan incelemeler sonucu potansiyel enerji tasarruf noktalarının, yüksek hava fazlalık katsayısı ile çalıştırılma ve reküperatörün 1sı transfer alanının yetersiz kalması olduğu görülmüştür. Bu noktalara yapılacak iyileştirmeler ile, yıllık 150.910\$ tasarruf elde edileceği ve yıllık 678,500 kg CO ${ }_{2}$ emisyon salınımının önlenebileceğini belirtmiştir. Akın, [42] ergimiş cürufun sahip olduğu 1sı enerjisinin geri kazanılmasına olanak sağlayacak yenilikçi bir sistem tasarlanmıştır. Ayrıca, tasarlanan sistemin maliyet muhasebesi yapılmış ve ticari yönden kullanılabilirliği analiz edilmiştir. Deng, [43] çelik endüstrisinde cüruf soğutma işleminde atık ısının geri kazanılması için kullanılan 1S1 borusu 1S1 değiștiricisini incelemiștir. Isı değiștiricisini temsil eden ana parametreler, deneysel ve teorik olarak araştırılarak en uygun işletme koşulları termodinamiğin birinci ve ikinci kanunları ile belirlenmiştir. Sonuçta, 1s1 transfer oranı ve 1s1 transfer katsayısının, su akış hızına bağlı olarak arttığını ortaya koymuştur. Jouhara, [44] çelik üretiminde açığa çıkan yüksek sıcaklıktaki ısının geri kazanımı için düz 1S1 borusu 1S1 eşanjörü tasarlamış ve test etmiştir. Tasarlanan 1S1 değiştiricisinin termal performansı ve 1sı transfer hızı araştırılmıştır. Sonuçlar, sistemin 1S1 geçiş kabiliyetinin yüksek sıcaklık kaynağının sıcaklığından çok fazla etkilendiğini göstermektedir. Chang, [45] atık ısı geri kazanımıyla birlikte, demir çelik sektöründe kok üretim sürecini modellenmiştir. Gerçek fabrika verileri, literatür verileri ile karşılaştırılmıştır, söndürme moduna ve atık ısı geri kazanımına dayanan kok üretim süreci termodinamik, tekno-ekonomik ve $\mathrm{CO}{ }_{2}$ emisyon analizi olmak üzere üç metot ile analiz edilmiştir. Çalışmalar sonucunda atık 1sı geri kazanımı ile enerji ve ekonomik verimliliğin artacağı ve $\mathrm{CO}_{2}$ emisyonlarının azaltılabileceği tespit edilmiştir.

\subsection{3. Çimento ve Orman Sektöründe Atık Isı Geri Kazanımının İncelendiği Çalışmalar}

Karellas, [46] endüstride firın ve ön isitıcıların radyasyon ve konveksiyon kayıpları nedeniyle sisteme giren ısının geri kazanımı için su buharı, Rankin ve organik Rankine çevrimlerini karşılaştırılmıştır. Neticede organik Rankine çevriminin daha verimli olduğu görülmüştür. Ekonomik açıdan bakıldığında, atık 1sı geri kazanım tesisi ile geri kazanılan 1sı enerjisi ile ciddi miktarlarda para tasarrufu yapılabileceği görülmüştür. Tütüncü, [47] çimento fabrikalarında atık 1S1 geri kazanım sistemlerinin enerji verimliliğine olan etkileri, sistemin termodinamik olarak incelenmesi ve geliştirilmesi amaçlanmıştır. Güneş, [48] bir orman endüstri tesisinde kojenerasyon sistemi ile elde edilebilecek elektrik enerjisi ve 1si enerjisinin potansiyelini araştırmıştır. Sistemin uygulanması ile beraber tesis için hem elektrik hem de 1s1 enerjisi üretilebileceği belirtilmiştir. Sistemin yıllık 1,8 milyon TL enerji tasarrufu sağlayacağı ve kendini 2 ay içerisinde amorti edeceği görülmüştür. 


\subsubsection{Gıda Sektöründe Atık Isı Geri Kazanımının İncelendiği Çalışmalar}

Aneke, [49] enerjiyi yoğun olarak kullanan cips üretim sürecinin fritöz bölümüne vurgu yaparak, 1s1 geri kazanımının önemini vurgulamıştır Fritöz bölümünden çıkan atık ısının elektrik enerjisine çevrilmesi ve bu çevrim için bir çift 1sı kaynağ sistemi kullanımını önermektedir. Önerilen teknolojinin şu anda $216 \mathrm{~kW}$ kapasiteli olan tesisin günlük en yüksek elektrik ihtiyacının yaklaşık \%92'sini üretebildiğini göstermektedir. Yaşam döngüsü değerlendirme çalıșması, üretilen elektriğin, kömürle çalışan geleneksel bir elektrik santralinden üretilen elektriğin yerini almak için kullanımı halinde CO 2emisyonunu 139,580 kg/y1l azaltabileceğini göstermektedir. Manno, [50] endüstriyel makarna üretim sürecini incelenmiş ve kurutma işleminden gelen atık ısıyı geri kazanmak için bir adsorpsiyon çevrimi tasarlamış ve elde edilebilecek enerji tasarruflarını değerlendirmiştir Yapılan analizler sonucu elde edilen veriler, \%40-50 aralığında 1s1 enerjisi tasarrufu sağlanabileceğini göstermiştir.

\subsubsection{Enerji Üretim Tesisinde Atık Isı Geri Kazanımının İncelendiği Çalışmalar}

Eyriboyun, [51] Zonguldak Çatalağzı Termik Elektrik Santrali'nin yoğuşturucu soğutma suyu atık 1sısının, yerleşim yerlerinin 1sıtılmasında kullanılmasını incelenmiştir. Kullanılacak olan ısı pompası sistemiyle yoğuşturucu soğutma suyu atık ısısının geri kazanılarak konut 1sıtılmasında kullanılmasının hem ekonomik kazanç sağlayacağ hem de doğal kaynakların korunması hem de çevre kirliliğinin azaltılması amaçlanmıştır. Yapılan analiz sonuçlarına göre; işletme giderleri ve enerji tasarrufu bakımından 1sı pompası sistemi avantajlı olsa bile ilk yatırım maliyetinin yüksek olması ve de konuyu sahiplenen resmi bir kurum olmaması nedeniyle bu ısının kullanılamadığından bahsetmiştir. Enç ve Kasırga, [52] Depo Gazı Enerji Üretim Tesisinde oluşan ve atmosfere atılan atık ısının değerlendirilmesini araştırmışlardır. Dizayn edilen atık 1sı geri dönüşüm sistemiyle 1sı geri kazanımı sağlanmış ve bu 1 sı sera 1sıtılmasında kullanılmıştır.

\section{MATERYAL VE METOT}

Sunulan bu çalışmada orman endüstri sektöründe hizmet veren bir tesisin atık 1sı geri kazanım potansiyeli araştırılmıştır. Tesiste ısıtma, sıcak su ve proses ihtiyaçlarını tedarik edebilmesi için 2 adet doğalgaz yakıtlı alev borulu kızgın sulu kazan sistemi kullanılmaktadır. Mevcut sistemin enerji, 1S1 transferi ve ekonomik çözümlemeleri [28] yapılarak elde edilen sonuçlar neticesinde atik 1sıdan yararlanmak için ön hava 1sıtıcı tasarımı (reküperatör) ve uygulaması yapılmıştır.

\subsection{Enerji Hesaplamaları}

$\mathrm{Bu}$ bölümde yakıt olarak doğalgaz kullanılan kazanlardan atık baca gazı olarak çıkan enerjinin büyüklügünü tespit etmek, ön 1sitıcı ile ne kadarlık kısmının tekrar kazanılabileceğini hesaplamak için enerji analizi yapılmıştır. Tesiste kullanılan doğalgazın \%92'si metan, geri kalan \%8’lik kısmı propan, bütan, az miktarda etan ve karbondioksitten oluştuğu kabul edilmiştir. Doğal gazın özellikleri Çizelge1'de verilmiştir. İçeriğinde bulunan metan moleküllerinin kimyasal yapısının basitliği nedeniyle yanma işlemi kolay olup, tam yanma gerçekleşmektedir. Kapalı formülünün çıkarılabilmesi için doğalgazın kimyasal içeriğine ve hacimsel yüzde değerlerine ihtiyaç duyulmaktadır. Hava ile yakıtın tam yanması sonucu açığa çıkan yanma ürünleri ve mol miktarları Eşitlik 1'de gösterilmiştir [53].

Çizelge 1. Doğal gazın özellikleri

\begin{tabular}{|l|c|c|}
\hline Yakıt & $\begin{array}{c}\text { Alt Isıl Değer } \\
\left(\mathbf{H}_{\mathbf{u}}\right)[\mathbf{k J} / \mathbf{k g}]\end{array}$ & $\begin{array}{c}\text { Üst Isıl Değer } \\
\left(\mathbf{H}_{\mathbf{o}}\right)[\mathbf{k J} / \mathbf{k g}]\end{array}$ \\
\hline Doğal Gaz & 45000 & 50000 \\
\hline Metan & 50050 & 55530 \\
\hline Propan & 46340 & 50330 \\
\hline Bütan & 45370 & 49150 \\
\hline
\end{tabular}

$\mathrm{C}_{(\mathrm{x}+2 \mathrm{y}+3 \mathrm{z}+4 \mathrm{t}+5 \mathrm{u}+6 \mathrm{~d}+\mathrm{f})} \mathrm{H}_{(4 \mathrm{x}+6 \mathrm{y}+8 \mathrm{z}+10 \mathrm{t}+12 \mathrm{u}+14 \mathrm{~d})}$

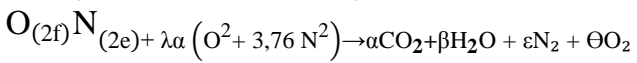

Yanma reaksiyonu neticesinde ürün olarak $\mathrm{CO}_{2}$, $\mathrm{H}_{2} \mathrm{O}, \mathrm{O}_{2}$ ve $\mathrm{N}_{2}$ meydana gelmektedir. Yanma ürünlerine ait mol miktarları kmol cinsinden kimyasal denkleştirme yapılarak hesaplanabilir. 
Toplam baca gazı miktarı kmol cinsinden Eşitlik 2 ile hesaplanmıştır.

$\mathrm{n}_{\mathrm{bg}}=\mathrm{n}_{\mathrm{O}_{2}}+\mathrm{n}_{\mathrm{CO}_{2}}+\mathrm{n}_{\mathrm{H}_{2} \mathrm{O}}+\mathrm{n}_{\mathrm{N}_{2}}$

Bacadan çıkan egzoz gazlarını meydana getiren bileşenlerin her birine ait mol kesirleri Eşitlik 3 ile hesaplanmıştır.

$\mathrm{x}_{\mathrm{CO}_{2}}=\frac{\mathrm{n}_{\mathrm{CO} 2}}{\mathrm{n}_{\mathrm{bg}}}, \mathrm{x}_{\mathrm{H}_{2} \mathrm{O}}=\frac{\mathrm{n}_{\mathrm{H} 2 \mathrm{O}}}{\mathrm{n}_{\mathrm{bg}}}, \mathrm{x}_{\mathrm{N}_{2}}=\frac{\mathrm{n}_{\mathrm{N}_{2}}}{\mathrm{n}_{\mathrm{bg}}}, \mathrm{x}_{\mathrm{O}_{2}}=\frac{\mathrm{n}_{\mathrm{O}_{2}}}{\mathrm{n}_{\mathrm{bg}}}$

Egzoz gazlarının ortalama özgül ısı Eşitlik 4 ile hesaplanmıştır [53].

$\mathrm{c}_{\text {port }}=\mathrm{c}_{\mathrm{p}\left(\mathrm{CO}_{2}\right)} \mathrm{x}\left(\mathrm{x}_{\mathrm{CO}^{2}}\right)+\mathrm{c}_{\mathrm{p}\left(\mathrm{O}_{2}\right)}\left(\mathrm{x}_{\mathrm{O}} \boldsymbol{\partial}+\mathrm{c}_{\mathrm{p}\left(\mathrm{H}_{2} \mathrm{O}\right)} \mathrm{x}\left(\mathrm{x}_{\mathrm{H}_{2} \mathrm{O}}\right)+\mathrm{c}_{\mathrm{p}\left(\mathrm{N}_{2}\right)} \mathrm{x}\left(\mathrm{x}_{\mathrm{N}_{2}}\right)\right.$

$\dot{\mathrm{c}}_{\mathrm{p}}$ değeri ise; özgül 1sı değerini ifade etmekte olup birimi kJ/kg.K olarak alınmıştır. Yakıtın yanması sonucu elde edilen yakıt enerjisi Eşitlik 5 ile hesaplanmıştır.

$\dot{\mathrm{E}}_{\text {yakit }}=\dot{\mathrm{Q}}_{\text {yakit }} \mathrm{xH}_{\mathrm{u}}$

Eşitlikteki $\dot{Q}_{\text {yakıt }}$ birim zamanda sarf edilen yakıt olup birimi $\mathrm{m}^{3} / \mathrm{s}^{\text {'dir. }} \mathrm{H}_{\mathrm{u}}$ ise yakıtın alt $1 \mathrm{~s} 1$ değerini ifade etmekte olup birimi $\mathrm{kJ} / \mathrm{m}^{3}$ 'tür. Baca gazlarının birim zamandaki kütlesi, yakıtın ve havanın birim zamandaki kütlelerinin toplamına eşittir.

$\dot{\mathrm{m}}_{\text {yakıt }}+\dot{\mathrm{m}}_{\text {hava }}=\dot{\mathrm{m}}_{\text {baca gazı }}$

Havanın birim zamandaki kütlesi (kg/s);

$\dot{\mathrm{m}}_{\text {hava }}=\frac{\dot{\mathrm{m}}_{\text {yaktt }} \times 4,76 \times \lambda \times \text { Ma }_{\text {hava }}}{\text { Ma }_{\text {yakıt }}}$

Eşitlik ile hesaplanır. $\dot{\mathrm{m}}_{\text {yakıt }}$ yakıtın birim zamandaki kütlesini, $\lambda$ hava fazlalık katsayısını, $\mathrm{Ma}_{\text {hava }}$ havanın mol ağırlığını ve $\mathrm{Ma}_{\text {yakıt }}$ ise yakıtın mol ağırlığını ifade etmektedir. Yakıtın birim zamandaki kütle değeri (kg/s);

$\dot{\mathrm{m}}_{\text {yakit }}=\dot{\mathrm{Q}}_{\text {yakit }} \mathrm{x} \rho_{\text {yakit }}$
Eşitlik 8 ile hesaplanır. Eşitlikteki $\dot{\mathrm{Q}}_{\text {yakıt }}$ değeri, birim zamanda sarf edilen yakıt olup gaz yakıtlar için birimi $\mathrm{m}^{3} / \mathrm{s}$ 'dir. $\rho_{\text {yakıt }}$ ise yakıtın ortam şartlarındaki yoğunluğunu ifade etmektedir. Gaz yakıtlar için yakıt yoğunluğu ortam koşullarına göre ( 1 atm basınç ve $\mathrm{T}_{\mathrm{o}}$ ortam sicaklığ ${ }^{\circ} \mathrm{K}$ );

$\rho_{\text {yakıt }}=\frac{M_{\text {yaktt }} \times 273}{22,4 \times T_{0}}$

Baca gazlarının birim zamandaki kütle ve mol miktarları Eşitlik 10 ve 11'den hesaplanmıştır.

$\dot{\mathrm{m}}_{\text {baca gazl }}=\dot{\mathrm{m}}_{\text {yakit }}+\frac{\dot{\mathrm{m}}_{\text {yaktt }} \mathrm{x} 4,76 \mathrm{x} \lambda \times \text { Mahava }}{\mathrm{Ma}_{\text {yaktt }}}$

$\dot{\mathrm{n}}_{\text {baca gazı }}=\frac{\dot{\mathrm{m}}_{\text {baca gazı }}}{\text { Maca gazı }}$

Yakıtın yanması sonucu açığa çıkan enerjinin bir kısmı baca gazları ile beraber atmosfere atılmaktadır. Baca gazlarının enerjisi; baca gazı sıcaklığından ileri gelen duyulur isı (Eşitlik 12) ve su buharına ait gizli ısıdan (Eşitlik 13) meydana gelir.

$\dot{\mathrm{E}}_{\mathrm{bg}, \mathrm{duy}}=\dot{\mathrm{n}}_{\mathrm{bg}} \mathrm{x} \dot{\mathrm{c}}_{\mathrm{p}, \mathrm{ort}} \mathrm{x}\left(\mathrm{T}_{\mathrm{bg}}-\mathrm{T}_{\mathrm{o}}\right)$

$\dot{\mathrm{E}}_{\mathrm{bg}, \mathrm{giz}}=\left(\dot{\mathrm{n}}_{\mathrm{bg}} \mathrm{x} \mathrm{x}_{\mathrm{H}_{2} \mathrm{O}}\right) \times \mathrm{xM}_{\mathrm{H}_{2} \mathrm{O}} \mathrm{X} \mathrm{h}_{\mathrm{fg}}$

Baca gazından dışarı atılan (kayıp) duyulur ve gizli isi yüzdeleri Eşitlik 14 ve 15 ile hesaplanmıştır.

$\% \mathrm{e}_{\text {kay,duy }}=\frac{\dot{\mathrm{E}}_{\text {bg,duy }}}{\dot{\mathrm{E}}_{\mathrm{ya}}} \times 100$

$\% \mathrm{e}_{\text {kay,giz }}=\frac{\dot{\mathrm{E}}_{\mathrm{bg}, \text { giz }}}{\dot{\mathrm{E}}_{\mathrm{ya}}} \times 100$

Yanma işleminin gerçekleştiği proseslerden enerji kaybının çok büyük bir bölümü baca gazları kayıplarından meydana gelmektedir. Kazan kayıpları hesaplanırken meydana gelen kayıplar baca gazi kayıpları ve diğer kayıplar olmak üzere iki ana baslıkta ele alınarak hesaplamalar yapılmıştır. Baca gazlarının sahip olduğu enerji duyulur ve gizli enerjinin toplamından hesaplanmıştır. Toplam baca gazı kayıpları, yüzde baca gazı kayıpları ve kazan kayıpları Eşitlik 16, 17 ve 18 ile hesaplanmıştır [54]. 
$\dot{\mathrm{E}}_{\text {top,bg }}=\dot{\mathrm{E}}_{\text {bg,duy }}+\dot{\mathrm{E}}_{\text {bg,giz }}$

\% baca kayıpları $=\frac{\dot{\mathrm{E}}_{\text {top,bg }}}{\dot{\mathrm{E}}_{\text {yakıt }}} \times 100$

$\%$ kazan kyp. $=\%$ baca kyp. $+\%$ diğer kyp.

Bacadan atılarak kayba uğrayan enerjinin yıllık parasal değeri, Eşitlik 19 ile hesaplanmıştır. Kazanın 24 saat, 30 gün ve 12 ay balistiği kabul edilmiştir. Verilen eşitlikteki $m$ değeri, $1 \mathrm{~m}^{3}$ doğalgaza ait birim fiyatı göstermektedir.

$\mathrm{P}_{\text {kay }}=\frac{\dot{\mathrm{E}}_{\mathrm{bg}, \mathrm{duy}}+\dot{\mathrm{E}}_{\mathrm{bg}, \text { giz }}}{4,18 \times \mathrm{H}_{\mathrm{u}}} \times \mathrm{xm} \times 60 \times 60 \times 24 \times 30 \times 12$

Egzoz edilen baca gazlarının soğutulması ile beraber geri kazanım sağlanan enerji, çiylenme noktasının üzerindeki bir sıcaklığa $\left(\mathrm{T}_{\mathrm{bg}, \mathrm{c}}\right)$ soğutulması halinde yalnızca duyulur enerjinin bir kısmı geri kazanılabilir. Hem duyulur hem de gizli enerjiden geri kazanım sağlanabilmesi için çiylenme noktasının altına inilmelidir.

$\mathrm{P}_{\mathrm{su}}=\mathrm{x}_{\mathrm{H}_{2} \mathrm{O}} \times \mathrm{P}_{\mathrm{atm}}$

Denklemde verilen $\mathrm{x}_{\mathrm{H}_{2} \mathrm{O}}$ baca gazları içerisindeki suyun mol kesri, $\mathrm{P}_{\mathrm{atm}}$ ise atmosfer basıncıdır. Geri kazanılan enerji miktarı, enerji kütle denkliği yazılarak Eşitlik 21 ile hesaplanmıştır.

$\dot{\mathrm{E}}_{\text {geri,kaz }}=\dot{\mathrm{n}}_{\mathrm{bg}} \mathrm{x} \dot{\mathrm{c}}_{\mathrm{p}, \mathrm{ort}} \mathrm{x}\left(\mathrm{T}_{\mathrm{bg}, \mathrm{g}}-\mathrm{T}_{\mathrm{bg}, \mathrm{c}}\right)$

Geri kazanılan 1sı miktarının yüzdesel değeri Eşitlik 22 ile hesaplanmıştır.

$\% \dot{\mathrm{e}}_{\text {geri-kazan }}=\frac{\dot{\mathrm{E}}_{\text {geri,kaz }}}{\dot{\mathrm{E}}_{\text {yakit }}} \times 100$

\subsection{Isı Transfer Hesaplamaları}

Yapılan enerji analizi neticesinde elde edilen baca gazı enerjisinden geri kazanım sağlayabilmek için ne büyüklükte 1 sı değiştirici tasarlanması gerektiğini belirlemek için 1s1 transfer analizi yapılmıştır. Isı transferi için, 1sı değiştiricinin geometrik özellikleri toplam boru say1s1, 1S1 transfer yüzey alanı, boru tarafı ve gövde tarafının basınç düşümleri hesaplanmıştır. Basınç kayıplarını karışlayabilmek için ihtiyaca duyulacak fan kapasitesi belirlenmiştir. Kazanlardan atık 1sı olarak atılan sicak baca gazı, sisteme dahil edilecek bir 1S1 değiştiricisi vasıtası ile soğutulurken, elde edilecek 1sı sayesinde kazana ait yakma havasına on 1sıtma yapılması amaçlanmaktadır. Söz konusu sistem için çapraz akışlı 1sı değiştirici tasarlanması öngörülmüştür. Is1 değiştiricisinin içerisindeki boru demetlerinden 1sıtılmak istenen yakma havası, demetlerin üzerinden baca gazi geçirilerek 1s1 geçişi sağlanmaktadır. Seçilen 1sı değiştiricinin her iki akışkanı içinde isi transfer katsayısı hesaplanmalıdır. Boru demetleri içinden akan hava tarafinın 1sı transfer katsayısını hesaplamak için Eşitlik 23'de verilen Dittus-Boelter denkleminden faydalanılmıştır [55]. Eşitlikten elde edilen Nusselt sayısı Eşitlik 24'e uygulanmış ve hava tarafı için 1S1 transfer katsayısı hesaplanmıştır.

$\mathrm{Nu}=0,023 \times \operatorname{Re}^{0,8} \times \operatorname{Pr}^{0,4} \quad \operatorname{Re}>10000$

$\mathrm{h}_{\text {hava }}=\frac{{\mathrm{Nu} \times \mathrm{k}_{\text {hava }}}_{\mathrm{d}_{\mathrm{i}}}}{\mathrm{d}}$

Yukarıdaki eşitliklerde verilen, Nu: Nusselt sayısını, Re: Reynolds sayısını, Pr:Prandtl sayısını, $\mathrm{h}_{\text {hava havanın taşınım 1sı transfer katsayısını }}$ $\left(\mathrm{W} / \mathrm{m}^{2} . \mathrm{K}\right), \mathrm{k}_{\text {hava }}$ havanın 1 sıl iletkenlik katsayısını (W/m.K) ve $d_{i}$ ise borunun iç çap ölçüsünü (m) ifade etmektedir. Seçilen 1sı değiştiricinin boru içi hava tarafının 1sı transfer katsayısını hesaplamak için Eşitlik 25 ve 26 kullanılmıştır [56].

$v_{\text {hava }}=\frac{4 \times m_{\text {hava }}}{\rho_{\text {hava }} \times \pi \times\left(d_{i}\right)^{2}}$

$R e=\frac{\rho_{\text {hava } x d_{i} \times v_{\text {hava }}}}{\mu_{\text {hava }}}$

Egzoz gazının taşınım katsayısını hesaplamak için sistemdeki boru demetlerinin siralı tip mi, şaşırtmalı tip mi olduğu önem arz etmektedir. Sunulan çalışmada boru dizilişleri sıralı tip olarak belirlenmiştir. Bu belirlemeye göre Nusselt sayısı Eşitlik 27 ile hesaplanmıştır [57].

$\mathrm{Nu}_{\mathrm{D}}=0,27 \times \operatorname{Re}_{\max }{ }^{0,63} \times \operatorname{Pr}^{0,36} \times\left(\operatorname{Pr} / \operatorname{Pr}_{\mathrm{s}}\right)^{0,25}$ 
$1000<\mathrm{Re}_{\max }<2 \times 10^{5}$

Sisteme ait bacadan çıkan egzoz gazına ait ortalama hız;

$\mathrm{V}_{\mathrm{bg}, \text { ort }}=\frac{\dot{\mathrm{m}}_{\mathrm{bg}}}{\rho_{\mathrm{bg}} \times \mathrm{L}_{\mathrm{z}} \times \mathrm{L}_{\mathrm{y}}}$

şeklinde hesaplanmıştır. Eşitlikte verilen $L_{z} \quad 1 S 1$ değiştiricisinin uzunluğunu, $\mathrm{L}_{\mathrm{y}}$ ise 1S1 değiştiricisinin genişliğini göstermektedir. Baca gazına ait maksimum hız Eşitlik 29'dan [56];

$\mathrm{V}_{\mathrm{bg}, \max }=\mathrm{V}_{\mathrm{bg}, \text { ort }} \times \frac{\mathrm{S}_{\mathrm{z}}}{\left(\mathrm{S}_{\mathrm{z}}-\mathrm{d}_{0}\right)}$

şeklinde hesaplanmaktadır. $S_{z}$ boruların arasındaki boşlukların $\mathrm{z}$ yönündeki mesafesini göstermektedir. Baca gazı tarafina ait Re sayısı da Eşitlik 30 ile hesaplanmıştır [56].

$\operatorname{Re}_{\text {max }}=\frac{\rho_{\text {bg }} \times d_{0} \times V_{\text {bg,max }}}{\mu_{\text {bg }}}$

Baca gazı tarafına ait ısı taşınım katsayısı Eşitlik 31 ile hesaplanmıştır [58]. Eşitlikte belirtilen, $\mathrm{k}_{\mathrm{bg}}$ baca gazına ait 1sıl iletkenlik katsayısını ve $d_{0}$ ise borunun dış çap ölçüsüdur.

$h_{b g}=\frac{N_{D} \times k_{b g}}{d_{0}}$

Nusselt sayısı Eşitlik 32'den hesaplanır. Eşitlikte yer alan $\mathrm{F}$ düzeltme faktörünü ilgili tablolardan $\left(\mathrm{N}_{\mathrm{z}}=10\right.$ ’ y yönündeki boru demeti sayıs1) 0,98 seçilmiştir [58].

$\mathrm{Nu}_{\mathrm{D}, \mathrm{N}_{\mathrm{z}}}=\mathrm{Nu}_{\mathrm{D}} \mathrm{XF}$

toplam 1sı transfer katsayısı Eşitlik 33 ile hesaplanmıştır. Eşitlikte bulunan $\mathrm{k}_{\text {boru }}$, 1s 1 değiştirici boru malzemesine ait isıl iletkenlik katsayısıdır [59,60].

$\mathrm{U}_{0}=\frac{1}{\frac{\mathrm{r}_{0}}{\mathrm{r}_{\mathrm{i}}} \times \frac{1}{\mathrm{~h}_{\text {hava }}}+\frac{\mathrm{r}_{0}}{\mathrm{k}_{\text {boru }}} \times \ln \left(\frac{\mathrm{r}_{0}}{\mathrm{r}_{\mathrm{i}}}\right)+\frac{1}{\mathrm{~h}_{\mathrm{bg}}}}$

Soğuk ve sıcak akıșkanlar arasındaki sıcaklık farkı $(\Delta \mathrm{T})$, 1sı değiştiricinin giriş kısmında çıkış kısmına nazaran daha yüksektir. Sıcaklık farkı, çıkış kısmına doğru üstel olarak azalır. Bu değer, logaritmik ortalama sicaklık fark1 olarak adlandırılır ve aşağıdaki denklem ile hesaplanır $[59,60]$.

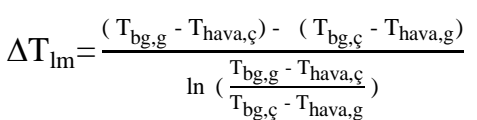

Sistemin ait 1sı transfer alanı Eşitlik 35 ile hesaplanmıştır.

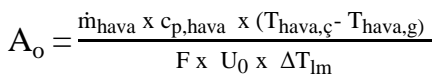

Boru ve gövde taraflarına ait basınç düşümleri Eşitlik 36 ile hesaplanmıştır.

$\Delta \mathrm{P}_{\text {boru }}=f \times \frac{\mathrm{L}_{\text {top }}}{\mathrm{d}_{\mathrm{i}}} \times \rho_{\text {hava }} \times \frac{\mathrm{V}^{2} \text { hava }}{2}$

Denklemde verilen $\mathrm{L}_{\text {top }}$,toplam boru uzunluğunu ve $f$, sürtünme faktörünü temsil etmektedir. Sürtünme faktörü için literatürde kabul görmüş birçok denklem mevcuttur. Sunulan çalışmada bu denklemlerden düz dairesel borular için kullanılan Eşitlik 37'deki Filonenko denklemi kullanılmıştır. [61].

$\mathrm{f}=0,046 \times \operatorname{Re}^{-0,2} \quad 3 \times 10^{4}<\operatorname{Re}<10^{6}$

Boru tarafında oluşan basınç düşümünü aşabilmek için gerekli fana ait güç Eşitlik 38 ile hesaplanmıştır.

$\dot{\mathrm{W}}_{\text {fan,hava }}=\frac{\dot{\mathrm{Q}}_{\text {hava }} \times \Delta \mathrm{P}_{\text {top }}}{\eta_{\text {fan }}}$

Yukarıdaki denklemde belirtilen $\dot{Q}_{\text {hava }}$ havaya ait hacimsel debiyi, $\eta_{\text {fan }}$ ise verimi ifade etmekte olup, \%85 alınmıștır. [62]. Baca gazı kısmında boru demeti üstünden akan baca gazına ait giriș ve çıkış arasındaki basınç düşümü Eşitlik 39 ile

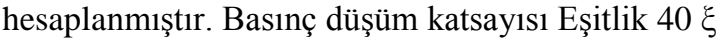
ile gösterilir ve boru demeti dizilimine göre değişkenlik gösterir [63].

$\Delta \mathrm{P}_{\text {gövde }}=\xi \times\left(\frac{\rho_{\text {bg }} \times V^{2} \text { bg,ort }}{2}\right)$ 
Bu denklem sıralı boru dizilimi için;

$\xi=2 \times\left(\frac{S_{y}}{d}-1\right)^{-0,5} \times \operatorname{Re}^{-0,5} \times N_{z}$

Sistemde meydana gelecek basınç düşümünü aşabilmek için gerekli fan gücü denklem 3.41 ile hesaplanmıştır. Denklemde belirtilen; $\mathrm{T}_{\mathrm{bg}, \mathrm{g}}$ baca gazı giriş sıcaklığını, $P_{d}$ ise basınç düşümü ile atmosfer basıncının toplamını ifade eder. $P_{i}$ atmosfer basıncını ifade etmekte olup, k ise özgül 1sı oranıdır. Bu çalışmada $\eta_{\text {fan }} \% 85$ olarak kabul edilmiştir [63].

$\dot{\mathrm{W}}_{\mathrm{fan}, \mathrm{bg}}=\frac{\dot{\mathrm{m}}_{\mathrm{bg}} \times \mathrm{c}_{\mathrm{p}-\mathrm{bg}} \times \mathrm{T}_{\mathrm{bg}-\mathrm{g}} \times\left[\left(\frac{\mathrm{P}_{\mathrm{d}}}{\mathrm{P}_{\mathrm{i}}}\right)^{\left.\frac{\mathrm{k}-1}{\mathrm{k}}-1\right]}\right.}{\eta_{\mathrm{fan}}}$

\subsection{Ekonomik Analiz}

Sistem için ekonomik analiz, bir önceki bölümde tasarlanan ısı değiştirici vasıtası ile elde edilecek yakıt tasarrufu ve amortisman süresini hesaplayabilmek için yapılmaktadır. Ekonomik analiz yapılırken; ilk yatırım maliyetleri, ekonomik ömür, senelik bakım ve işletme harcamaları, senelik kar miktarı, hurda değeri ve faiz oranları önem arz etmektedir. Kurulacak sistem vasitası ile geri kazanılan enerjinin yıllık maddi değeri (tasarruf miktarı), Eşitlik 42 ile hesaplanmıştır. Eşitlikteki $\mathrm{m}$ değeri $1 \mathrm{~m}^{3}$ doğalgaza ait birim fiyatı göstermektedir.

$\mathrm{F}_{\text {geri,kaz }}=\frac{\dot{\mathrm{E}}_{\text {geri-kaz }}}{4,18 \times \mathrm{H}_{\mathrm{u}}} \times \mathrm{mx} 60 \times 60 \times 24 \times 30 \times 12$

Ekonomik analiz yapılırken net bugünkü değer metodundan faydalanılmıştır. Bu metot gelecek dönemde alınacak ve/veya verilecek paranın şimdiki değerini belirlemek amacı ile kullanılmaktadır. Şimdiki ve gelecekteki gelir ile giderler herhangi bir alternatif için bilinebiliyorsa, uygun bir faiz oranı kullanılarak alternatife ait şimdiki değer hesaplanabilir. Eşitlik 43 ile net bugünkü değer NBD hesaplamaları yapılmıştır. Eşitlikteki n, yatırımın faydalı ömrünü $A_{i}$, yatırımdan sağlanacak nakit girişlerini, $r$ faiz oranını, H yatırımın faydalı ömrü sonundaki hurda değerini, $C_{i}$ yatırım için yapılması gereken nakit çıkışlarını ifade etmektedir [64].
$\mathrm{NBD}=\sum_{\mathrm{i}=1}^{\mathrm{n}} \frac{\mathrm{A}_{\mathrm{i}}}{(1+\mathrm{r})^{1}}+\frac{\mathrm{H}}{(1+\mathrm{r})^{\mathrm{n}+1}}-\sum_{\mathrm{i}=1}^{\mathrm{n}} \frac{\mathrm{C}_{\mathrm{i}}}{(1+\mathrm{r})^{\mathrm{i}}}$

Kazan sistemine uygulanacak olan projenin amortisman süresi geri ödeme suresi ile hesaplanmıştır. Yıllara göre sağlanan gelirin değişmediği kabulü ile yatırım tutarının, I yıllık yatırım gelirine, $K$ bölünmesi ile geri ödeme suresi hesaplanmıştır (Eşitlik 44).

Geri Ödeme Süresi $=\frac{\mathrm{I}}{\mathrm{K}}$

\section{BULGULAR VE TARTIŞMALAR}

Çalışmanın yapıldığı endüstriyel tesiste 2 adet 18.000.000 kcal/h kapasiteli 180/120 ${ }^{\circ} \mathrm{C}$ kıgın sulu alev duman borulu kazan bulunmaktadır. Bu endüstriyel tesiste yakıt olarak doğalgaz kullanılmaktadır. Endüstriyel tesise ait kazan otomasyon sisteminden alınan veriler Çizelge 2'de sunulmuştur. Alınan veriler neticesinde yapılan enerji analizinde toplam baca gazı kayıplarının yaklaşık olarak \%17 olduğu hesaplanmıştır. Bu kayıp tesiste bulunan her iki baca için de büyük bir enerji potansiyeline sahiptir. Kayıp baca gazlarının yıllık maddi değeri her iki baca için toplamda 1.119.792 TL'dir. İki kazanın yıllık yakıt tüketimi toplamda 13.320.644 $\mathrm{m}^{3}$ 'tür. Kazanlar y1lın 365 günü ve 24 saat çalışmaktadır. Kazanların saatlik yakıt tüketimi $1520 \mathrm{~m}^{3}$, günlük tüketimi ise 36.494,9 m³'tür. Çizelge 3'de kazan verilerine göre yapılan analiz sonuçları sunulmuştur.

Çizelge 2. Otomasyon sisteminden alınan veriler

\begin{tabular}{|l|c|c|}
\hline Alınan Değerler & 1.Kazan & 2.Kazan \\
\hline Hava fazlalık katsayısı $\lambda$ & 1,13 & 1,17 \\
\hline Baca gazı çıkış sıcaklığ ${ }^{\circ} \mathrm{C}$ & 156 & 152 \\
\hline Yakma havası ${ }^{\circ} \mathrm{C}$ & 30 & 30 \\
\hline
\end{tabular}

Baca gazının kayıp enerjisi, baca gazının sıcaklığıyla doğru orantılı olarak değişmektedir. Baca gazı sıcaklığı arttıkça, baca gazının duyulur enerji kaybı artmaktadır. Baca gazı gizli enerji kaybı artan sıcaklıktan etkilenmemektedir. Baca gazı gizli kayıp değeri doğrudan baca gazı içerisindeki su buharı ile doğru orantılıdır. Kazan verimi baca gazı sıcaklığı ile ters orantılı olarak değişmektedir. Baca gazı sıcaklığı arttıkça kayıplar artmakta, bu da kazandan elde edilen verimin düşmesine neden 
olmaktadır. Hava fazlalık katsayısının artması da toplam baca gazı miktarını arttırmaktadır. Artan baca gazı ile beraber duyulur baca gazı 1sı kayb1 artmakta ve dolayısı ile verim düşmektedir. Baca gazından kaybedilen kayıp isılar baca gazının soğutulması veya baca gazındaki su buharının yoğuşturulması ile büyük bir kısmı tekrar kazanılabilir. Su buharının yoğuşabilmesi için çiylenme sıcaklığının altına kadar soğutulması gereklidir.

Çizelge 3. Analiz sonuçları

\begin{tabular}{|l|c|c|}
\hline \multicolumn{1}{|c|}{ Analiz } & 1.Kazan & 2.Kazan \\
\hline Baca Gazı Duyulur Isı Kaybı (\%) & 6,78 & 6,72 \\
\hline Baca Gazı Molar Kesri $\left(\mathrm{H}_{2} \mathrm{O}\right)$ & 0,1629 & 0,1638 \\
\hline Baca Gazı Gizli Isı Kaybı (\%) & 10,32 & 10,32 \\
\hline Baza Gazı Toplam Isı Kaybı (\%) & 17,1 & 17,04 \\
\hline Baca Gazı Kaybının Bedeli (TL/yıl) & 560.880 & 558.912 \\
\hline Çiylenme Sıcaklığ1 & 62,24 & 62,86 \\
\hline Yakıt Debisi (kg/s) & 0,1 & 0,1 \\
\hline Yakıt Enerjisi (kJ/s) & 4448 & 4448 \\
\hline Hava Debisi (kg/s) & 1,78 & 1,82 \\
\hline Baca Gazı Debisi (kg/s) & 1,88 & 1,92 \\
\hline
\end{tabular}

\subsection{Sisteme Ait Hava Ön Isıtıcısının Dizaynı}

Tesiste bulunan kazandan çıkan $180^{\circ} \mathrm{C}$ sıcaklığındaki baca gazı ön 1sıtma ünitesine girmektedir. Ön 1sitıcıya (rekuperator) giren hava dış sıcaklığın etkisi ile beraber soğumaya başlar. Yaklaşık olarak $154-^{\circ} \mathrm{C}^{\prime}$ ye kadar soğuma olmaktadır. Aynı zamanda $30^{\circ} \mathrm{C}$ olan kazan yakma havas $160^{\circ} \mathrm{C}$ 'ye kadar 1sitılmaktadır. Baca gazına ait çıkış sıcaklık değeri çiylenme noktasının üzerinde olduğundan baca gazı içerisindeki su buharının çiylenmesi mümkün olmayacaktır. Sıcaklığı artan hava tekrar kazana verilir. Isınan havanın tekrar kazana verilmesi ile beraber kazan verimi artar. Kazan veriminin artması ile beraber daha iyi bir yanma meydana gelir ve kazan kayıpları azalır. Sistemde kullanılan kazanda bulunan brülör maximum hava sıcaklığının $80{ }^{\circ} \mathrm{C}$ ye kadar dayanım sağlamaktadır. Ön 1sıtma sistemi için tasarım yapilırken havanın $60-^{\circ} \mathrm{C}^{\prime}$ ye kadar 1sitılmas1 hedeflenmiştir. Ön 1sıtma sisteminde oluşabilecek ısı kayıplarını minimize etmek amacıyla dış kısmı yalıtım malzemesi ile çevrilmiştir. Hava ön ısıtıcısının içi de sıralı tip boru demeti ile çevrilmiştir. Boru demetinde yer alan boruların diş çapları $30 \mathrm{~mm}$, iç çapları ise $27 \mathrm{~mm}$ olup et kalınlığı $1,5 \mathrm{~mm}$ olarak seçilmiştir. Sistemin çiylenme sıcaklığ $\quad 60-^{\circ} \mathrm{C}$ olduğu için paslanma beklenmemektedir. Çiğlenme söz konusu olmayacağı için boru demetinde karbon çeliği kullanılmıştır. Ön ısıtıcı içerisinde yer alan borular yatayda 30 sıra, düşeyde 10 sıra olmak üzere toplamda 300 tanedir. Boru demeti etrafi karbon çeliği levha ile çevrilmiş olup, diğer kısmı $15 \mathrm{~cm}$ kauçuk köpük ( $\mathrm{k}=0,038 \mathrm{~W} / \mathrm{m} . \mathrm{K})$ ile çevrilerek izole edilmiştir. Boru demetinde yer alan boruların birbilerine olan mesafeleri enine ve boyuna eşit mesafede olacak şekilde konumlandırılmış ve 0,040 m olarak ayarlanmıştır. Boru demetinde yer alan her bir borunun boyu eşit ve $1 \mathrm{~m}$ olarak seçilmiştir. Ön 1sıtıcı içerisinde yer alan boru demetinden oluşan 1sı değiştiricinin malzemesi olarak seçilen karbon çeliğine ait isıl iletkenlik katsayısı k=60,5 W/m.K olarak hesaplamalarda kullanılmıştır. Hava ön isıtıcı içerisinde boru demeti 0,35'lik kısıma yerleştirilmiştir. Hava ön ısıtıcının yüksekliği ile kazan çıkışında yer alan baca gazı borusunun çapı ön 1sitıcının yüksekliğinden daha küçüktür. Ön 1sıtıcının yüksekliği $2 \mathrm{~m}$ olarak tasarlanmıştır. Kazan çıkışında bulunan bacanın çapı 1,5 m ve bacanın uzunluğu 12 m’dir. Ön 1sitıcıdan çıkan ve burada 1sıtılan havanın kazan brülörüne iletildiği hava kanalında oluşabilecek kayıpları minimize etmek için dış kısmı $10 \mathrm{~cm}$ kalınlığında cam yünü $(\mathrm{k}=0,040 \quad \mathrm{~W} / \mathrm{m} . \mathrm{K})$ ile kapatılmıştır. Tesiste aynı kapasitede iki kazan olduğu için her bir kazan için birer tane ön 1sıtıcı eklenmiştir. Sisteme ait ön 1sıtma ünitesinin şematik gösterimi, kazan sistemdeki yerleşimi ve enerjikütle denklikleri Şekil 1'de gösterildiği gibidir.

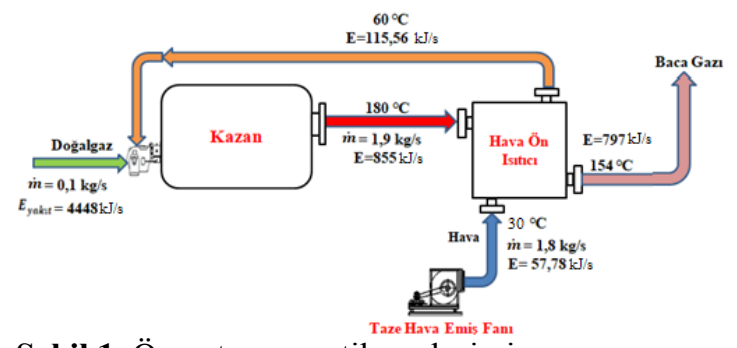

Şekil 1. Ön 1sıtıcı şematik yerleşimi

\subsection{Sistem için Tasarlanan Hava Ön Isıtıcısının Analiz Sonuçları}

Kazan sisteminde kullanılan ön 1sıtıcı için yapılan tasarıma ait hesaplamalar Çizelge 4'de, tasarlanan 
1S1 değiştiricisin izometrik ve kesit görünüşü de Şekil 2'de verilmiştir. Hava için yapılan hesaplamalarda, Nusselt sayıs1, Nu=38,95, 1S1 iletim katsayısı, $\mathrm{k}_{\text {hava }}: 0,024 \mathrm{~W} / \mathrm{m} . \mathrm{K}$ ve $\mathrm{d}_{\mathrm{i}}: 0,027 \mathrm{~m}$ olarak hesaplanmıştır. Baca gazı için yapılan hesaplamalarda, Nusselt say1s1, $N u_{D}=65,65$, $\mathrm{k}_{\text {hava }}: 0,035 \mathrm{~W} / \mathrm{m} . \mathrm{K}$ ve $\mathrm{d}_{\mathrm{o}}: 0,03 \mathrm{~m}$ olarak alınmıştır. $\mathrm{L}_{\text {top; }}$; toplam boru boyu uzunluğudur ve $300 \mathrm{~m}$ olarak alınmıştır. Bir boruya ait yüzey alanı 0,094 $\mathrm{m}^{2}$ 'dir. Boru tarafı için yapılan hesaplamalarda, $f$ sürtünme faktörü: 0,016 , $\mathrm{L}_{\text {top }}: 300 \mathrm{~m}, \mathrm{~d}_{\mathrm{i}}: 0,027 \mathrm{~m}, \rho_{\text {hava }}: 1,164 \mathrm{~kg} / \mathrm{m}^{3}$ $\left(30^{\circ} \mathrm{C}\right.$ için) ve $\mathrm{V}_{\text {hava }}: 7,42 \mathrm{~m} / \mathrm{s}$ olarak alınmıştır. Gövde tarafı için yapılan hesaplamalarda, basınç düşümü katsayısı $(\xi): 0,144, \rho_{\text {hava }}: 4,5 \mathrm{~kg} / \mathrm{m}^{3}$ ve ortalama baca gazı hızı $\left(\mathrm{V}_{\mathrm{bg} \text {, ort }}\right)^{2}=5,17 \mathrm{~m} / \mathrm{s}$ olarak alınmıştır. Boru tarafı için yapılan hesaplamalarda, havanın hacimsel debisi $\dot{\mathrm{Q}}_{\text {hava }}: 0,422 \mathrm{~m}^{3} / \mathrm{s}$ ve fanın verimi, $\eta_{\mathrm{fan}}: \% 85$ olarak alınmıştır. Gövde tarafi için yapılan hesaplamalarda, kütlesel debi $\left(\dot{\mathrm{m}}_{\mathrm{bg}}\right): 1,9 \mathrm{~kg} / \mathrm{s}$, baca gazı giriş sıcaklığ 1 $\left(\mathrm{T}_{\mathrm{bg}, g}\right): 180{ }^{\circ} \mathrm{C}$ ve baca gazı özgül 1s1s1 $\left(c_{p, b g}\right): 0,33 \mathrm{kcal} / \mathrm{Nm}^{3 \circ} \mathrm{K}$ olarak alınmıştır. Ekonomik analizlerde; geri kazanılan enerji, $\dot{\mathrm{E}}_{\text {geri,kaz }}=10181,2 \mathrm{~kJ}$, yakıtın alt $1 \mathrm{sil}$ değeri, $\mathrm{H}_{\mathrm{u}}=34535 \mathrm{~kJ} / \mathrm{m}^{3}$ ve $1 \mathrm{~m}^{3}$ doğalgazın birim fiyatı, $f=0,075 \mathrm{TL} / \mathrm{m}^{3}$ olarak alınmıştır. Hesaplamalar sonucunda 164.528,34 TL y1llik tasarruf elde edildiği görülmüştür. Ön 1sitıcının ilk yatırım maliyeti 62.670,80 TL'dir. Kurulan ön 1sitıcının ekonomik ömrü 15 yıl, faiz oranı \%4 ve hurda değeri ' 0 ' olarak alınmıştır. Sistemin büyük tamir ve bakım maliyetleri $25.000 \mathrm{TL}$, işletme maliyeti 40.000 TL'dir. Geri ödeme süresi 7 aydır.

Çizelge 4. Kazan sisteminde kullanılan ön 1sıtıcı için yapılan tasarıma ait hesaplamalar

\begin{tabular}{|c|c|c|c|c|c|c|c|c|c|c|c|c|}
\hline & & ${ }^{T} \mathbb{C}$ & $\underset{(\mathrm{kg} / \mathrm{s})}{\mathrm{m}}$ & $\underset{(m / s)}{V}$ & $\begin{array}{l}V_{\max } \\
(\mathrm{m} / \mathrm{s})\end{array}$ & $\mathrm{Nu}$ & $\begin{array}{c}\boldsymbol{h} \\
\left(W / \boldsymbol{m}^{2} \cdot K\right)\end{array}$ & $\begin{array}{l}L_{\text {top }} \\
(m)\end{array}$ & $\begin{array}{c}\boldsymbol{k} \\
(W / m \cdot K)\end{array}$ & $\underset{\left(m^{2}\right)}{A}$ & $\begin{array}{c}\Delta P \\
(k P a)\end{array}$ & $\begin{array}{l}\text { Güf } \\
(k W)\end{array}$ \\
\hline \multirow{2}{*}{$\begin{array}{c}\text { Boru Tarafi } \\
\text { Hava }\end{array}$} & Giriş & 30 & \multirow{2}{*}{1,8} & \multirow{2}{*}{\multicolumn{2}{|c|}{7,42}} & 3895 & 3467 & \multirow{4}{*}{300} & \multirow{4}{*}{60,5} & \multirow{4}{*}{28,2} & \multirow{2}{*}{5,69} & \multirow{2}{*}{0,0469} \\
\hline & Çıkıș & 60 & & & & & & & & & & \\
\hline \multirow{2}{*}{\begin{tabular}{|c|} 
Gövde Tarafı \\
Baca Gazı
\end{tabular}} & Giriş & 180 & \multirow{2}{*}{1,9} & \multirow{2}{*}{2,32} & \multirow{2}{*}{8,02} & \multirow{2}{*}{65,65} & \multirow{2}{*}{76,59} & & & & \multirow{2}{*}{0,0086} & \multirow{2}{*}{0,03} \\
\hline & Çıkıss & 154 & & & & & & & & & & \\
\hline
\end{tabular}

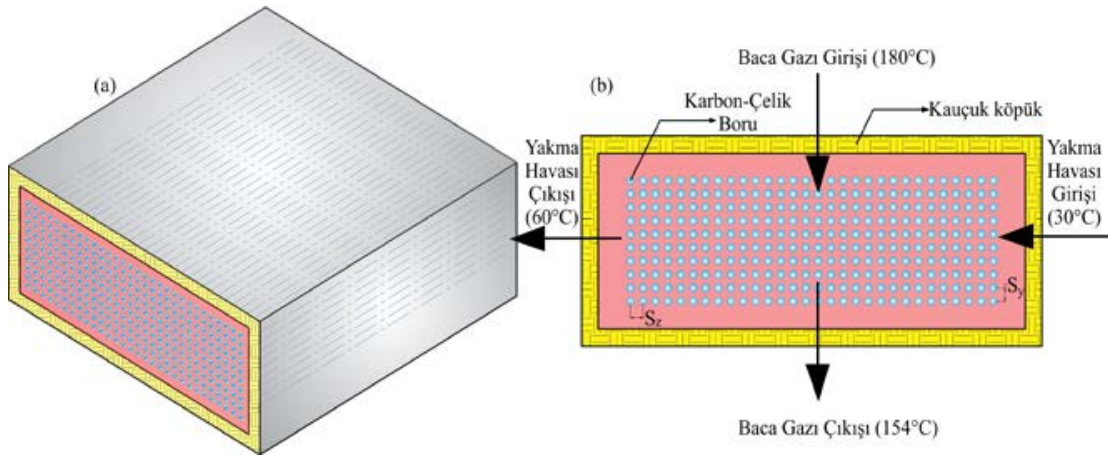

Şekil 2. Tasarlanan 1sı değiştiricisin izometrik ve kesit görünüşü

\section{SONUÇLAR VE ÖNERİLER}

$\mathrm{Bu}$ çalışmada, bir sanayi kuruluşuna ait 2 adet kızgın sulu alev borulu kazanda enerji verimliliği çalışmaları yapılmış olunup, enerji analizleri, 1sı transferi analizi ve ekonomik analizler için çeşitli hesaplamalar yapılmıştır. Yapılan analiz ve hesaplamalar sonucu elde edilen sonuçlar aşağıda maddeler halinde sunulmuştur:
Sisteme ait kazanların yıllık yakıt tüketimi ortalama $13.320 .644 \mathrm{~m}^{3} / \mathrm{y} 1 \mathrm{l}$ civarındadır. Yakıtın yıllık parasal değeri 6.232.587,4 TL'dir.

Kazan bacalarından çıkan gazın toplam 1sı kaybı \%17 civarındadır. Baca gazı kaybının yıllık bedeli her iki baca için toplamda 1.119.792 TL'dir.

Kazan çıkışından atılan baca gazına ait sıcaklık $180{ }^{\circ} \mathrm{C}$ 'dir. Kazandan atılan bu sicak gazın geri 
kazanımı için bir ön 1sıtıcı imal edilmiştir. Ön ısıtıcı ilk yatırım maliyeti 62.670,80 TL, tamir ve bakım maliyeti 25.000 TL ve işletme maliyeti olarak 40.000 TL olarak hesaplanmıştır. Sistemin ekonomik ömrünün 15 yıl ve geri ödeme süresinin ise 7 ay olacağı hesaplanmıştır.

> Yapilan hesaplamalar sonucunda yıllık tasarruf miktarının 164.528,34 TL ve toplam yakit tasarrufunun $\quad 1.121 .410,23 \quad$ TL $\quad$ olacağ görülmüştür.

Ayrica söz konusu ön 1sitıcı uygulaması ile 1sitılan kazan yakma havası sayesinde kazan verimi artacak, beraberinde de atmosfere salınan $\mathrm{CO}_{2}$ oranı azalacaktır. Azalan $\mathrm{CO}_{2}$ oranı ile beraber baca gazı kaynaklı çevre kirliliği de azalacaktır. Atık 1sı geri kazanımın sağlanabileceği benzer kazan uygulamalarında aynı metot ile enerji ve yakıt tasarrufu sağlanılabileceği düşünülmektedir. $\mathrm{Bu}$ geri kazanım yönteminin benzer uygulamalar için kullanılması önerilebilir.

\section{KAYNAKLAR}

1. Angin, B., 2007. Cam Sanayinde Geleneksel Yakıtlar Yerine Doğal Gaz Kullanımının Enerji Ekonomisi Açısından İncelenmesi. Yüksek Lisans Tezi, Mersin Üniversitesi. Mersin, 1-68.

2. Selbaş, R., 1992. Atık Isı Enerjisinden Yararlanma Yöntemleri ve Uygulamaları, Akdeniz Üniversitesi F.B.E, Yüksek Lisans Tezi, Antalya, 1-57.

3. Willems, D., 2006. Advanced System Controls and Energy Savings for Industrial Boilers, Transactions of the Citrus Engineering Conference, 52, 11- 22.

4. Güngör, A., 1995. İklimlendirmede Enerji Geri Kazanımında Isı Borulu Isı Değiştiriciler, Makine Mühendisleri Odası, II.Ulusal Tesisat Mühendisliği Kongresi ve Sergisi Bildiriler Kitab1, 639-655.

5. Ersöz, M.A., 2002. Baca Gazlarındaki Atık Isının Isı Borusu ile Geri Kazanımının Araştırılması, Gazi Üniversitesi F.B.E, Yüksek Lisans Tezi, Ankara,1- 133.

6. Ersöz, M., 2009. Baca Gazlarındaki Atık Isının Isı Borusu İle Geri Kazanımının Deneysel
İncelenmesi, IX. Ulusal Tesisat Mühendisliği Kongresi, İzmir, 133-141.

7. Ürün, E.,2010. Atık Baca Gazlarından Isı Geri Kazanımının Deneysel Olarak İncelenmesi, Karabük Üniversitesi F.B.E, Yüksek Lisans Tezi, Karabük, 1-71.

8. Remeli, M., 2015. Simultaneous Industrial Waste Heat Recovery and Power Generation Using Heat Pipe Assisted Thermoelectric Generator, Manufacturing Engineering College of Science Engineering and Health RMIT University, Master's Thesis, Australia, 1-158

9. Jouhara, H., 2017. Experimental Investigation on a Flat Heat Pipe Heat Exchanger for Waste Heat Recovery in Steel Industry, 1st International Conference on Sustainable Energy and Resource Use in Food Chains, Berkshire-UK, 1-15.

10. Ogulata, R. T., Doba, F., \& Yilmaz, T. (1999). Second-law and experimental analysis of a cross-flow heat exchanger. Heat transfer engineering, 20(2), 20-27.

11. Şahan, A.M., 1999. HVAC Uygulamalarında Is1 Geri Kazanımı, IV. Ulusal Tesisat Mühendisliği Kongresi, İzmir, 151-161.

12. Atalay, B., 1998. Waste Heat Recovery Using Regenerative Heat Exchanger, Çukurova University Institute of Natural and Applied Sciences, Master's Thesis, Adana,1-96

13. Goel, N., 2012. Design and Performance Analyses of Condensing Heat Exchangers for Recovering Water and Waste Heat from Flue Gas, Lehigh University, Department of Mechanical Engineering, Master's Thesis, Ann Arbor, 1-107

14. Yamankaradeniz, N., 2007. Tekstil Sanayiinde Atık Isıdan Yararlanılarak Enerji Tasarrufunda Klasik Sistem ile Is1 Pompasının Karşılaştırılması, Uludağ Üniversitesi Müh. Mim. Fakültesi Dergisi, 12(1), 115-124.

15. Yamankaradeniz, N., 2009. Soğutma Tekniği ve Isı Pompası Uygulamaları, Dora Yayıncıl1k, 2, 13-14.

16. Muslu, M. 2017. Is1 pompası destekli 1s1 geri kazanım cihazının farklı sıcaklıklardaki performans analizi, Master's thesis, Balıkesir Üniversitesi Fen Bilimleri Enstitüsü, 1-72.

17. Farshi, L.G., 2018. Thermodynamic Analysis of a Cascaded Compression Absorption Heat 
Pump and Comparison with Three Classes of Conventional Heat Pumps for the Waste Heat Recovery, Applied Thermal Engineering Journal, 128, 282-296.

18. Gibbs, B.M., 1987. Boiler Fuel Savings by Heat Recovery and Reduced Stanby Losses, Heat Rec. Systems and CHP Journal, 7, 151-157.

19. Butcher, T.A., Litzke W., 1994. Condensing Economizers For Small Coal- Fired Boilers and Furnaces, U.S.mEnergy Pittsburgh Energy Technology Center, Master's Thesis, New York, 1-80.

20. Çıtır, H., 2013. Endüstriyel Tav Fırınında Ekonomizer Tasarımı, Karabük Üniversitesi Enerji Sistemleri Mühendisliği, Yüksek Lisans Tezi, Karabük, 1-50.

21. He, B., 2014. Thermodynamic Analysis of a Low-Pressure Economizer Based Waste Heat Recovery System for a Coal-Fired Power Plant, Energy Journal, 65, 80-90.

22. Kılınç, H., 2016. Endüstriyel Tav Fırını Bacalarından Atık Isının Geri Kazanımı, İskenderun Teknik Üniversitesi Mühendislik ve F.B.E, Yüksek Lisans Tezi, Hatay, 1-56.

23. Aras, H., 1991. Doğal Gaz Yakan Sistemlerde Baca Gazından Isı Geri Kazanımı, Anadolu Üniversitesi F.B.E, Yüksek Lisans Tezi, Eskişehir,1-60.

24. Selimli, S., 2012. Endüstriyel Tav Fırını için Reküperatör Tasarımı, Karabük Üniversitesi F.B.E, Yüksek Lisans Tezi, Karabük, 1-73.

25. Willems D., 2006. Advanced System Controls and Energy Savings for Industrial Boilers, Transactions of the Cit. Eng. Conference, USA, 11-22.

26. Cortina, M., 2006. Flue Gas Condenser for Biomass Boilers, Lulea University of Technology Department of Applied Physics and Mechanical Engineering, Master's Thesis, Sweden, 1-76.

27. Ünlü, C., 2008. Buharlı Sistemlerde Enerji Geri Kazanımı, Tesisat Mühendisliği Dergisi, 108, 53-63.

28. Terhan, M., 2010. Atatürk Üniversitesi Isıtma Sistemi Kazan Bacalarında Isı Geri Kazanım Potansiyelin Araştırılması, Atatürk Üniversitesi F.B.E, Yüksek Lisans Tezi, Erzurum, 1-192.
29. Wang, D., 2012. Coal Power Plant Flue Gas Waste Heat and Water Recovery, Applied Energy Journal, 91, 341-348.

30. Görgülü, B., 2013.Atık Isı Kaynaklı Çift Etkili Absorpsiyonlu Soğutma Sisteminin Termodinamik Analizi, Süleyman Demirel Üniv, Yüksek Lisans Tezi, Isparta, 1-99.

31. Yağlı, H., 2013. Atık Isının Organik Rankine Çevrimi ile Kullanılabilirliği ve Ekserjisi, 9. Ulusal Temiz Enerji Semp., Konya, 394-401.

32. Peris, B., 2015. Experimental Study of an ORC for Low Grade Waste Heat Recovery in a Ceramic Industry, Energy Journal, 85, 534-542.

33. Seyedkavoosi, S., $2017 . \quad$ Exergy-Based Optimization of an Organic Rankine Cycle for Waste Heat Recovery from an Internal Combustion Engine, Applied Thermal Engineering Journal, 126, 447-457.

34. Ramirez, M., Epelde, M., de Arteche, M. G., Panizza, A., Hammerschmid, A., Baresi, M., \& Monti, N. 2017. Performance evaluation of an ORC unit integrated to a waste heat recovery system in a steel mill. Energy Procedia, 129, 535-542.

35. Srikanth, S., 2003. Analysis of Failures in Boiler Tubes Due to Fireside Corrosion in a Waste Heat Recovery Boiler, Engineering Failure Analysis Journal, 10, 59-66.

36. Yaylacı, Ç., 2015. Konvansiyonel ve Atık Is1 Kazanlarda Buhar Üretimi Sürecinin Enerji ve Ekserji Analizleri, GTÜ, Yüksek Lisans Tezi, Gebze, 1-73.

37. Sharma, O.P., 2018. Thermodynamic Analysis of a Supercritical/Transcritical $\mathrm{CO}_{2}$ Based Waste Heat Recovery Cycle for Shipboard Power and Cooling Applications, Energy Con. and Manag., 155, 262-275.

38. Can, M., 2009.Waste-Heat Recovery Potential in Turkish Textile Industry: Case Study for City of Bursa, Renewable and Sustainable Energy Reviews Journal, 13, 663-672.

39. Koçlu, A., 2011. Tekstil Endüstrisi Boyama Prosesinde Plakalı Isı Değiştiricilerle Atık Isı Geri Kazanım Sistemi Enerji ve Ekserji Analizi, X. Ulusal Tesisat Mühendisliği Kongresi, İzmir, 1913-1925.

40. Kaşka, Ö., 2014.Energy and Exergy Analysis of an Organic Rankine for Power Generation from Waste Heat Recovery in Steel Industry, 
Energy Conversion and Management Journal, 77, 108-117.

41. Eyidoğan, M., 2014. Endüstriyel Tav Firınlarında Enerji Tasarrufu ve Emisyon Azaltım Fırsatları, Gazi Üniv. Müh. Mim. Fak. Dergisi, 29(4), 735-743,

42. Akın, S., 2016. Demir Çelik Endüstrisinde Ergimiş Cüruftan Elde Edilen Atık Isının Geri Kazanımı, Bursa Teknik Üniversitesi F.B.E, Bursa, 1-118.

43. Deng, Y., 2017. Investigation on Thermal Performance of Steel Heat Exchanger for Ground Source Heat Pump Systems Using Full-Scale Experiments and Numerical Simulations, App. Ther. Engineering, 91-98.

44. Jouhara, H., Almahmoud, S., Chauhan, A., Delpech, B., Nannou, T., Tassou, S. A., ... \& Arribas, J. J. (2017). Experimental investigation on a flat heat pipe heat exchanger for waste heat recovery in steel industry. Energy Procedia, 123, 329-334.

45. Chang, S., 2017. Modeling Thermodynamic and Techno-Economic Analysis of Coke Production Process with Waste Heat Recovery, Energy, 141, 435-450.

46. Karellas, S., 2013. Energetic and Exergetic Analysis of Waste Heat Recovery Systems in the Cement Industry, Energy Journal, 58, 147-156.

47. Tütüncü, G., 2012. Çimento Sektöründe Atık Is1 Geri Kazanım (WHR) Sisteminin Termodinamik İncelemesi, Ege Üniversitesi F.B.E, İzmir, 1-98.

48. Güneş, M.F., 2001. Energy and Cost Analysis of A Cogeneration System, Dokuz Eylül Üniversitesi F.B.E, Yüksek Lisans Tezi, İzmir, $1-138$.

49. Aneke, M.C., 2012. Optimising Thermal Energy Recovery, Utilisation and Management in the Process Industries, University of Northumbria, Master's Thesis, 1-210.

50. Manno, M., 2017.Adsorbent Materials for Low-Grade Waste Heat Recovery: Application to Industrial Pasta Drying Processes, Energy Journal, 140, 729-745.

51. Eyriboyun, M., 2017.Çatalağzı Termik Elektrik Santrali ile Bölgesel Isıtma Yapılabilirliğin Enerji Analizi, Isı Bil. ve Tek. Dergisi, 37(1), 139-146.
52. Enç, V., Kasırga, M., 2012. Depo Gazı Enerji Üretim Tesisi Baca Gazı Atık Isısının Seralarda Değerlendirilmesi: İstanbul Örneği, Tarih Kültür ve Sanat Araştırmaları Dergisi, 1(4), 298-309.

53. Çengel, Y.A., Boles, M.A., 2006.Thermodynamics an Engineering Approach, McGraw- Hill, USA, 1-865.

54. Terhan, M., Çomaklı, K. 2015. Baca Gazi Atik Isisi Ile Kazan Yakma Havasinin Ön Isitilmasinin Fizibilitesi. Engineer \& The Machinery Magazine, 56, 668.

55. Incropera, F.P., DeWitt, D.P., 1996, Introduction to Heat Transfer, John Wiley \& Sons, New York, 1-959

56. Cortina, M., 2006. Flue Gas Condenser for Biomass Boilers, Lulea University of Technology Department of Applied Physics and Mechanical Engineering, Master's Thesis, Sweden, 1-76

57. Gnielinski, V.., 2010. Heat Transfer in Cross Flow Around Single Rows of Tubes and Through Tube Bundles, in VDI Heat Atlas, ed. VDI, Springer Verlag, Berlin, Germany, 725-729.

58. Çengel, Y.A., 2011. Isı ve Kütle Transferi, Güven Bilimsel Yayınları, İzmir.

59. Kakaç, S., Liu, H., 1998. Heat Exchangers: Selection, Rating and Thermal Design, CRC Press, New York, 1-676

60. Chen, Q., Finney, K., Li, H., Zhang, X., Zhou, J., Sharifi, V., Swithenbank, J., 2012. Condensing Boiler Applications in the Process Industry, Applied Energy, 89, 30- 36.

61. Gaddis, E.S., 2010. Pressure Drop of Tube Bundles in Cross Flow, in VDI Heat Atlas, ed. VDI, Springer Verlag, Berlin, Germany, 1076-1091.

62. Hazell, D.D., 2011. Modeling and Optimization of Condensing Heat Exchangers for Cooling Boiler Flue Gas, Lehigh University, Department of Mechanical Engineering, Master's Thesis, 1-109.

63. Okka, O., 2006. Mühendislik Ekonomisine Giriş Problemler ve Çözümleri, Nobel Yayın Dağıtım, Ankara, 1-334. 